Pobrane z czasopisma Annales H - Oeconomia http://oeconomia.annales.umcs.pl Data: 26/04/2023 13:30:48

DOI:10.17951/h.2018.52.6.111-127

\begin{tabular}{lcl}
\hline & A N N A L E S \\
UNIVERSITATIS MARIAE CURIE-SKŁODOWSKA \\
LUBLIN - POLONIA \\
VOL. LII, 6 & SECTIO H \\
\hline
\end{tabular}

Military University of Technology in Warsaw. Institute of Organization and Management

WIOLETTA WEREDA

ORCID ID: https://orcid.org/0000-0002-6948-0239

weredawioletta@tlen.pl

\title{
Model of Building Stakeholder Engagement in the Functioning of the Organization - Trust and Risk
}

Model budowania zaangażowania interesariuszy w funkcjonowanie organizacji - zaufanie a ryzyko

Keywords: stakeholder involvement; trust building; risk, case study; UniGlass Polska Sp. z o.o. (limited liability company, LLC)

Słowa kluczowe: zaangażowanie interesariuszy; budowanie zaufania; ryzyko; studium przypadku; UniGlass Sp. z o.o.

JEL code: M31; M21; L22

\section{Introduction}

It is increasingly recognized nowadays that trust is an extremely important element of the social space and brings specific benefits, both for the organization and its stakeholders. These benefits relate not only to the strengthening of interpersonal relationships but also to improving the quality and effectiveness of the organization's functioning and development. However, trust in business relationships is always associated with the risk incurred when interacting with various interest groups. Very often the situation in the market requires managers to take advantage of opportunities and avoid threats at the expense of building commitment and trust with their internal and external stakeholders. The specific objective of this study is to determine the relationship between trust relationships and the risk borne by enterprises in the pro- 
cess of building stakeholder engagement in the activities of the business unit. The research methods used in the article are a literature query and verification of source materials, an expert method and a case study method.

\section{Building relationships based on trust in the organization}

To ascertain the most frequent definition of trust in the literature, one should include definitions presented mainly by sociologists. Among these is the distinguished Polish sociologist, Prof. Sztompka, according to whom trust is a kind of resource, capital, which, depending on the dimension it owns, allows for the adoption of a specific type of assumption regarding the future uncertain actions of other people [Sztompka, 1999, p. 96]. Sztompka, treating trust as an extremely important aspect of the social bond, formulates statements about the community, such as the fact that human actions are always directed towards the future; furthermore, we are dependent on others and every man has a large field of freedom; finally, people are unpredictable in their decisions. In his research, he identifies two types of trust: strategic and normative. The first strategic trust presents the expectations of people in relation to the behaviour of others, which can be defined as a forecast of the behaviour of the other person [Sztompka, 2007, pp. 155-157]. In turn, normative trust is a statement about how people should behave towards others, assuming that they should trust each other. Normative trust is therefore a belief that some share basic moral values and therefore should be treated by others as they would like to be treated. An important issue is the sense of ties with people as a result of perceiving them as members of their community whose interests should be taken seriously, which does not mean the mutual compatibility of political or religious views. In every successful economic relationship, the element that binds the community is trust, which is also a significant and measurable economic value. Furthermore, trust comes when the community shares a number of moral values to the extent that people can constantly expect predictable and sincere behaviour from each other [Fukuyama, 1997, p. 153; Jończyk, 2010, p. 140]. When others share our basic assumptions, we risk less by solving problems related to undertaking collective actions. Fukuyama's achievement was to identify the relationship between trust as a cultural trait and economic success. The author defines trust as a "mechanism based on the assumption that members of a given community are characterized by honest and cooperative behaviour, based on jointly defined norms" [Fukuyama, 1997, p. 38]. In general, it can be presumed that the stronger the conviction of mutual trust among the participants in the organization, the greater the willingness to cooperate, which also results from the subjective probability of its success. In connection with the above, it seems extremely important to undertake efforts to shape relations based on trust.

In every interaction, trust between individuals in private and organizational life is important for people. The process of building trust is always related to a certain 
amount of risk (a chance or a threat). People create expectations towards others that they will behave in a way which is beneficial and not harmful [Wereda et al., 2016, p. 46]. Trust is very important, especially in the situation when the trustor depends on the trustee's future actions to achieve her/his own goals and objectives [Lane, 1998]. It is an interactive process that involves (at least) two individuals learning about each other's trustworthiness [Zand, 1972; Zucker, et al., 1996].

The new concept of trust management, also called management by trust, is the answer to this need to build cooperation and involve all stakeholders in the organization. It can be defined as a set of actions to create systems and methods that allow individuals to make assessments and make decisions related to the reliability of potential risk operations, and enable their participants and system owners to grow and adequately represent their own credibility and systems [Grudzewski et al., 2009; Paliszkiewicz, 2013, pp. 100-105]. According to these authors, the following assumptions are important in managing trust:

- lack of trust and suspicion are often justified by a risky situation; in organizations that compete with each other, the costs of trusting the unreliable partner can be very high;

- in today's uncertain, highly dynamic and risky environment, you need to know exactly who you can trust and under what conditions;

- $21^{\text {st }}$-century societies are knowledge-based societies involving the creation of intelligence, in which the processes of generating knowledge determine their prosperity and source of wealth. In these processes, trust is one of the key success factors. Its absence leads to economic backwardness;

- in the future, trust will be a key element in any organization for knowledge management processes and "knowledge workers";

- inter-organizational, intra-organizational trust and the trust of customers and society is the capital of the company, and affects its efficiency.

It seems that the above statements justify the fundamental role of trust in building beneficial and long-term relationships both within the organization and with the environment. Nowadays, organizations based on learning and own agility are increasingly using relationships based on trust to achieve their own goals and development, minimizing risk and strengthening the competitive advantage. Furthermore, building the trust relationship allows the probability of achieving different benefits (minimizing threats and increasing opportunities from emerging risks) to be increased and additional financial, material, social and relational benefits to be gained.

In the literature on the subject, there are many theories and models regarding building trust, and thus relations based on trust. Only those selected that outline a specific approach in the context of risk are presented below.

Galford and Drapeau [2002] presented the SEEKER model with the critical elements of trust-building in the personal and organizational life:

- Show that you understand the needs of the person and/or group;

- Establish the guiding principles of how you will operate; 
- Explain the resources you will use in this work;

- Keep to the principles you have elaborated;

- Engage in constant, honest, two-way communication;

- Reinforce through consistent behaviours.

Furthermore, according to Ciancutti and Steding [2001], a trust-based culture is created by developing, implementing and maintaining a specific Trust Model formulated in cooperation with internal stakeholders (employees) and external ones. The Trust Model they describe includes the following guidelines: closure, commitment, communication, speedy resolution, respect and responsibility, and building it requires: involvement, contribution and creativity from all stakeholders.

At the same time, it should be noted that the literature also indicates behaviours characteristic of a high or low level of trust (Figure 1). Relational behaviours concern not only activities within the organization, but also acts of exchange between the organization and its stakeholders. It is recognized that the interest in relational exchange is caused by growing competitive pressure and the changeability of the environment. Organizations are moving away from treating relations with partners as a "zero-sum" game in which someone would have to lose to win [Jończyk, 2009, pp. 157-166], and are more inclined to long-term cooperation, where each party receives tangible benefits and can count on developing partnerships.

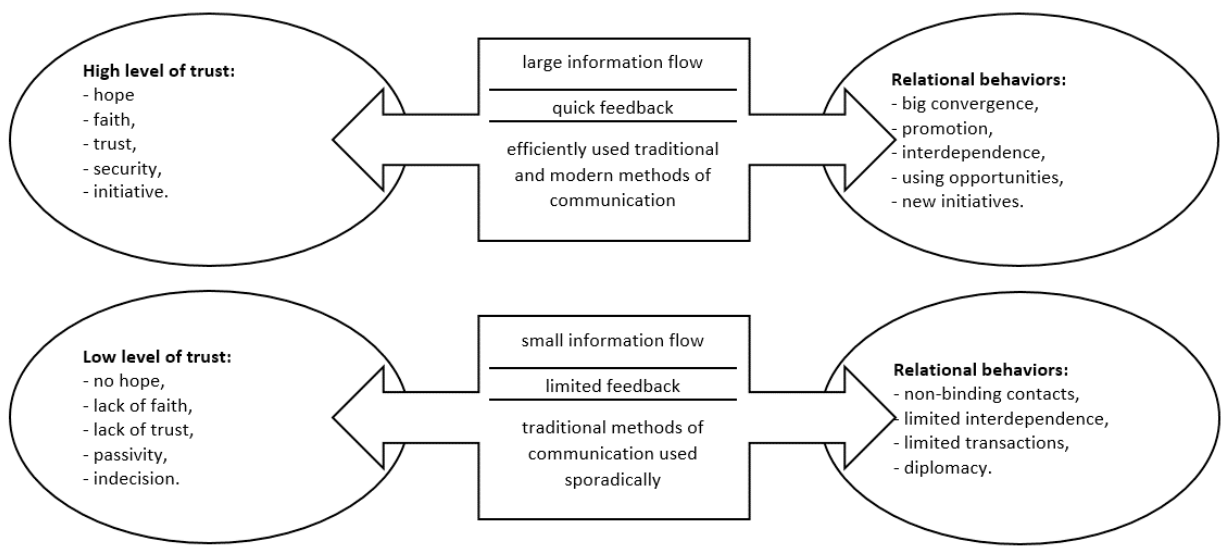

Figure 1. The trust level versus relational behaviour

Source: Author's own study based on Lewicki et al. [1998].

In summary, building relationships on trust is a long-lasting process as generally people distrust each other. According to many studies, trust is a very dynamic process; it is not static. Trust is built up gradually, reinforced by previous trusting behaviour and previous positive experiences from relations [Zand, 1972; McAllister, 1995; Lewicki, Bunker, 1996, pp. 114-139]. It needs time and interactions with many involved parties to be developed. Trust evolves according to the development 
of the relationship [Porras et al., 2004]. The trust building process starts with building credibility and reputation at the personal level [Covey, 2009] and grows at the organizational level with people's ability to trust themselves.

In the literature, one can find many links between the risk borne and building relationships based on trust in business. In relation to each significant risk in the organization, it is necessary to specify the actions that must be taken to reduce the risk to an acceptable level [Bourne, 2009]:

- in the case of low-risk (low probability and low impact), no action is taken to reduce the risk to an acceptable level, i.e. the risk is at an acceptable level;

- in the event of a high-level risk, measures should be identified and taken to reduce the risk to an acceptable level (e.g. transfer of risk, taking risk mitigation measures, withdrawing from risky activities or hedging against risks).

Planning for risk response involves developing a plan for dealing with risk factors. This plan should include a description of activities aimed at minimizing the frequency of occurrence of threats and their consequences for projects, while maximizing the positive effects. It should also include a division of roles and responsibilities for the implementation of activities related to the response to threats [Domańska-Szaruga, Simiński, 2017, pp. 121-122]. Business risk is a risk with different characteristics than strategic or operational risk. In this case, we deal with both a negative and a neutral dimension of risk (risk is a threat and an opportunity). This risk comes from outside the organization (systematic risk) and is a specific risk that arises inside the organization (non-systematic risk). The multidimensionality of business risk is the determinant of the appropriate conduct:

- systematic risk - prevention of negative effects of systematic risk, or mitigation of effects;

- unsystematic risk - reducing risks and taking advantage of opportunities [Woźniak, Wereda, 2018, pp. 41-49].

The risk is included in the specificity of the core business of each enterprise. Relations with partners on the market generate several important threats that cannot be eliminated, so one should limit their negative impact and take advantage of emerging opportunities. The dependence of the trust-risk-transaction costs leads to assumptions that the chances of limiting the negative effects of business risk factors in many cases should be seen in shaping relationships and cooperation with stakeholders (internal and external). Building relationship capital and strengthening cooperation fosters the creation of a climate of trust and reduces the risk.

There is also a risk category in the subject literature which indicates that the risk is "every phenomenon that affects our ability to achieve goals" [Murphy, 2008, p. 39]. The definition proposed by Hopkin is a definition that fits into the broad category and at the same time comprehensively and consistently reflects the nature of the impact of risk on contemporary organization [Hopkin, 2010, p. 12], assuming that the risk is "an event with the ability to influence (by limiting, aggravating or causing doubt) on a mission, strategy, projects, routine activities, goals, basic processes, key relationships 
and/or providing stakeholders with specific values". This definition is worth paying attention to, because it involves linking the organization and risk with different classes of stakeholders (internal and external), as well as joining individual time horizons of management processes. This definition should be treated as a basic one, as it refers to the inclusion of integrated management processes and also gives the possibility of the universal perception of risk (as a source of opportunities and threats).

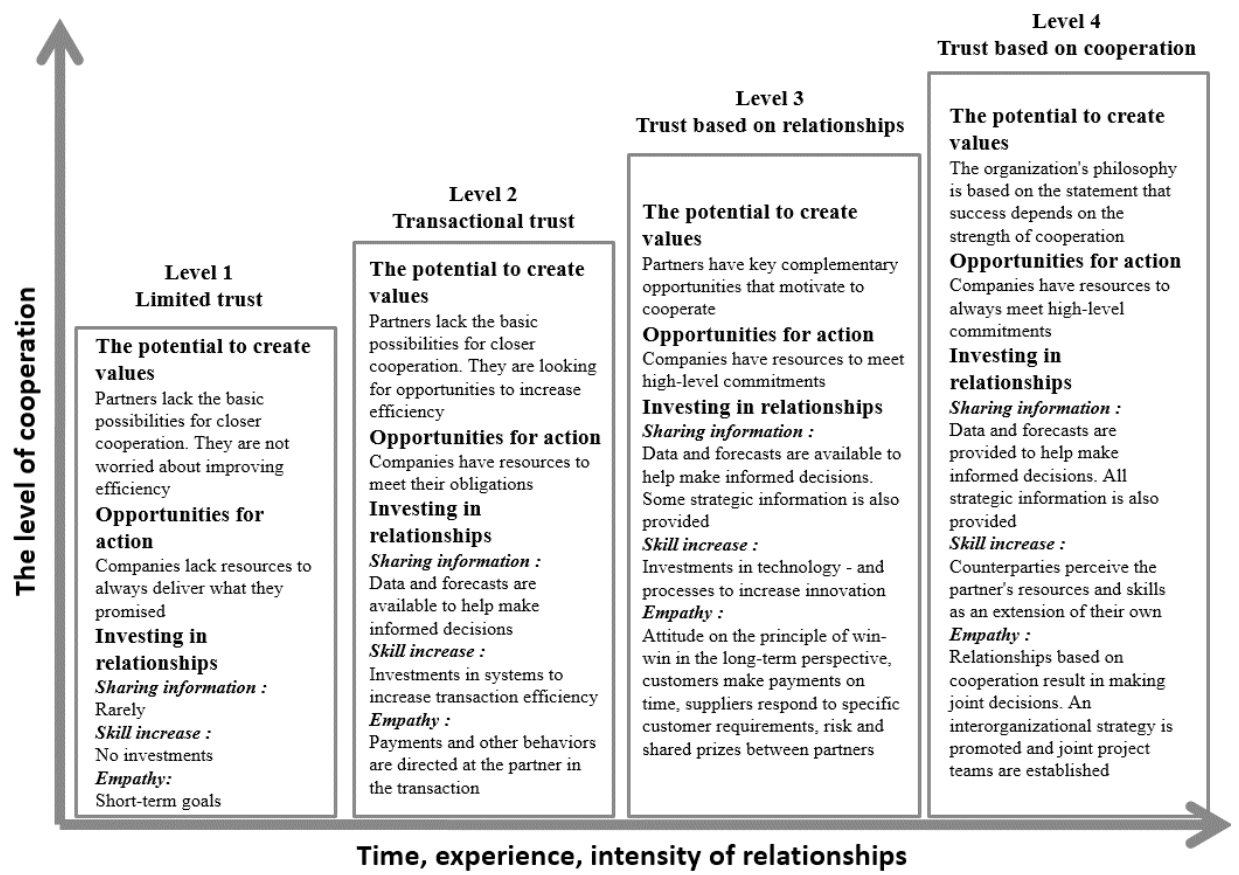

Figure 2. Trust maturity model and the intensity of building relationships with partners

Source: Author's own study based on Domańska-Szaruga, Simiński [2017, p. 116], Fawcett et al. [2012, p. 174], and Paliszkiewicz [2013, p. 103].

\section{A model for building stakeholder engagement in the functioning of the organization}

According to the literature, different studies have adopted different definitions that have reflected cross-discipline research and the debate about stakeholders. That is why many authors have defined "stake" as an interest in something, right to something, ownership to the organization, knowledge required, impact or influence on something, or contribution to some activity. The earliest definition was introduced by Stanford Research Institute in 1963 and it described "stakeholders" as those groups without whose support the organization would cease to exist. Many other scholars 
subsequently developed definitions on different criteria such as objectives, strategy, cooperation, building relations, trust, etc. [Wereda et al., 2016, pp. 28-29]. The classic definition of a "stakeholder" by Freeman is any group or individual who can affect or is affected by the achievements of the organization's objectives [Freeman, 1984, p. 46]. Furthermore, Freeman's hub-and-spoke depiction of the firm and its stakeholders was pioneering, suggesting that managers take the expectations and needs of different groups into account in their strategizing in addition to the shareholders, and manage these relationships accordingly [Freeman, 1984, p. 46]. The scholar also uses a different definition of stakeholders as "those groups who are vital to the survival and success of the corporation" [Freeman, 2004, pp. 58-64].

Table 1. Characteristics of stakeholders in the organization (criterion of influence and involvement)

\begin{tabular}{|c|c|}
\hline \multicolumn{2}{|r|}{ Stakeholders of the basic degree of influence and direct involvement } \\
\hline $\begin{array}{l}\text { 1. Internal and close } \\
\text { to them } \\
\text { (directly related to the } \\
\text { tasks of the company) }\end{array}$ & $\begin{array}{l}\text { Owners, shareholders, management, employees and their families, former employees, } \\
\text { pensioners, applicants for employment, apprentices, members of informal groups in the } \\
\text { enterprise, proxies, advisers, supervisory boards, works councils/employee organizations, } \\
\text { members in member organizations, their democratic bodies/authorities }\end{array}$ \\
\hline $\begin{array}{l}\text { 2. External } \\
\text { (related to the tasks } \\
\text { of the company in } \\
\text { a more or less direct } \\
\text { way) }\end{array}$ & $\begin{array}{l}\text { Shareholders, stakeholders, members of co-ownership bodies, persons influential towards } \\
\text { co-owners, representation of members in association bodies, competitors/non-industry } \\
\text { competitors, e.g. operating in the same labour market, capital, know-how, opinions, val- } \\
\text { ues, ideas; ad hoc competitors, commercial agencies and/or other intermediaries in sales } \\
\text { and supplies, development funds; strategic partners (business); customers/buyers/users/ } \\
\text { consumers; cooperatives, their members and unions; banks and other financial institutions, } \\
\text { dealers, brokers, lobbying organizations; consulting companies; consumer organizations, } \\
\text { employee organizations, trade unions, employers' associations, other industry and profes- } \\
\text { sional economic communities and arrangements, business associations, advertising and } \\
\text { marketing agencies, public relations, members of social and professional organizations }\end{array}$ \\
\hline \multicolumn{2}{|r|}{ Stakeholders of the second degree of influence and indirect involvement } \\
\hline $\begin{array}{l}\text { So-called general } \\
\text { environment - author- } \\
\text { ities at various levels } \\
\text { and regulatory institu- } \\
\text { tions in the economy } \\
\text { and social life }\end{array}$ & $\begin{array}{l}\text { Governmental and state organs, their agencies and members, including members of local } \\
\text { self-government bodies, deputies, senators and other politicians operating within the state } \\
\text { organs at various levels, decision-making bodies in the field of social, political, economic } \\
\text { and cultural life decisions, i.e. regulatory organizations/institutions operating on the labour } \\
\text { market, financial market, in social policy - appropriate ministries, government agencies } \\
\text { of state institutions, financial institutions, trust offices; judicial authorities; advocates of } \\
\text { consumer/governmental matters with interest groups, state employment agencies, tax } \\
\text { and customs services }\end{array}$ \\
\hline \multicolumn{2}{|r|}{ Stakeholders of further degrees of influence and further involvement } \\
\hline $\begin{array}{l}\text { 1. Opinion-forming } \\
\text { circles }\end{array}$ & $\begin{array}{l}\text { Mass media, journalists, journalists' organizations, editorial offices, correspondents (includ- } \\
\text { ing foreign), editorial offices of company's newspapers, press departments of institutions } \\
\text { and surrounding companies, universities and their authorities, students and their representa- } \\
\text { tions, university promotion departments, graduates' associations, councils employers and } \\
\text { graduates, leaders of views and opinions originating from various areas of public life - } \\
\text { influential representatives of cultural, educational, political, religious institutions, creative } \\
\text { associations, a wide audience of influential media, guests visiting enterprises }\end{array}$ \\
\hline $\begin{array}{l}\text { 2. Citizens' initiatives } \\
\text { and similar }\end{array}$ & $\begin{array}{l}\text { Non-governmental organizations that protect the natural environment, freedoms and civil } \\
\text { rights, culture; consumer associations; other grassroots institutions of public life; societies } \\
\text { acting to solve social and health problems, environmental protection organizations etc. }\end{array}$ \\
\hline $\begin{array}{l}\text { 3. The environment of } \\
\text { the enterprise and in- } \\
\text { ternational institutions }\end{array}$ & $\begin{array}{l}\text { Diplomatic missions, diplomats, consular offices of embassies; representatives of foreign } \\
\text { organizations and authorities; affiliations of international organizations }\end{array}$ \\
\hline
\end{tabular}

Source: Author's own study based on Wereda et al. [2016, pp. 30-42], Szwajca [2016, pp. 42-66], and Wójcik [2011]. 
In the process of adapting the organization to changes in the market, one of the most important aspects of modern enterprises is taking into account the involvement and benefits of stakeholders and building loyalty relationships with the environment, which may result in the development of various types of values (economic and non-economic). Moreover, without this mutual cooperation, long-term development and capital growth is not possible, which is why very often the value of an organization is determined by the right choice of sources that create the value, and influence the involvement of stakeholders and the proper management of trust-based relationships. A wider description of stakeholders and their level of impact and involvement in the organization is presented in Table 1. The cooperation of organizations with large-scale partners hinders the construction and maintenance of long-term relationships that will create a specific conjugate value. Sometimes a stakeholder/partner can be "addicted" to one organization. Cooperation with many entities who are simultaneously involved to a reasonable degree, gives greater freedom to all partners and is the source of improvements in the course of processes [Wereda, 2015, p. 221] and creating new values. Analysing various approaches to building relationships based on the trust of the organization with its stakeholders, Benson-Armer and Stickel [2000, pp. 20-26] recognize that building trust is necessary:

- to reduce uncertainty about what is achieved by, among other methods, strictly determining employee roles and common value systems, value communication and their formation;

- to reduce weaknesses in various situations, which can be partially achieved by dividing big problems into smaller ones;

- to reduce risk and learn from mistakes;

- to express faith in employees, e.g. in their competences and intentions;

- to limit prejudices, which translates into care, respect, mutual expectations and respect for diversity;

- to communicate in a clear, simple and understandable way, while minimizing all communication barriers.

According to many scholars and research institutes, stakeholder engagement is the process of influencing a variety of outcomes through consultation, communication, negotiation, compromise and relationship building, based on dialogue and cooperation over a long period of time. The most important elements of this process are:

- gaining stakeholder approval and support;

- minimizing their opposition and satisfying their needs as far as possible;

- anticipating what human risks and opportunities might arise;

- enabling plans to be made and managed;

- communicating effectively and reacting to each problem;

- cooperating and building trust in every level of the contact. 


\section{Trust and risk - a model for building stakeholder engagement in an enterprise, using the example of UniGlass Polska Sp. z o.o.}

UniGlass Polska Sp. z o.o. (limited liability company) is situated in Łomża, Poland, and is a manufacturer of glass panels, and has pride in professional glass and mirrors processing. The organization itself began in 2001, but the idea itself was born much earlier, as it was already in place in 1998. Two colleagues (Adam Wieczorek and Radosław Florczyk), who for many years had worked in a prestigious building company, decided to establish their own joint venture. In 2010, when one of the partners left the company (Adam Wieczorek), Dariusz Florczyk took his place. The situation was even more motivated by the actions of shareholders, especially Radosław Florczyk, under whose tenure the company has evolved exponentially. From the beginning of the consistently implemented activity, an investment and innovation programme aimed at dynamically increasing the quality of offered goods and services. Glazing production takes place using the world's highest-class machines and equipment, using the highest quality raw materials and production materials. The quality was constantly verified by all current and potential suppliers and constant inspection of the quality of goods offered was conducted. Inter-operational quality control of the manufactured products resulted in the creation of a brand not only in Poland, but also abroad - Lithuania, Romania, Slovakia, etc. [Quality Book of UniGlass Polska Sp. z o.o., 2011, pp. 3-5]. Furthermore, from the very beginning, the owners of the company have set up a developing strategy of quality and created the rules for relationship building with all interest groups, as employees, customers, suppliers and local authorities. Due to the fact that the company evolved rather quickly due to process innovativeness, at the end of 2017, the company already employed 100 people, of whom approximately $80 \%$ were production workers. The owner and managers highlighted that their market strategy is to introduce process and product innovations on the market [Wereda, 2015, pp. 225-228]. Until now, the company has gained a considerable amount of grants from the EU to develop the quality of products, produce their own machines and create new projects. The most important activities of the company are shown in Table 2 .

Table 2. Classification of the UniGlass Sp. z o.o. as the basis for risk identification

\begin{tabular}{|c|l|}
\hline $\begin{array}{c}\text { Business } \\
\text { area }\end{array}$ & \multicolumn{1}{c|}{ Type of activity } \\
\hline & $\begin{array}{l}\text { - theoretical and experimental research } \\
\text { - prototyping }\end{array}$ \\
Conducting & - cooperation with external institutions \\
R\&D works & $\begin{array}{l}\text { - adaptation of research results to the needs of the practice } \\
\text { - cooperation with machinery and equipment manufacturers } \\
\text { - implementation of results into practice }\end{array}$ \\
\hline
\end{tabular}




\begin{tabular}{|c|c|}
\hline $\begin{array}{l}\text { Business } \\
\text { area }\end{array}$ & Type of activity \\
\hline $\begin{array}{l}\text { Conducting } \\
\text { certification } \\
\text { activities }\end{array}$ & $\begin{array}{l}\text { - running a certifying unit } \\
\text { - issuing the Declaration of Conformity } \\
\text { - maintaining the conformity control system (Factory Production Control) required for certifi- } \\
\text { cation } \\
\text { - testing of the quality of raw materials and materials for production } \\
\text { - testing of the quality of finished products } \\
\text { - audits and records of audits }\end{array}$ \\
\hline $\begin{array}{l}\text { Economic } \\
\text { activity }\end{array}$ & $\begin{array}{l}\text { - production of double glazing using a wide range of functional glass } \\
\text { - transport of the main raw material for production } \\
\text { - execution of orders for institutional clients } \\
\text { - design and execution of orders for individual clients } \\
\text { - providing services for clients } \\
\text { - transport of finished products for customers } \\
\text { - after-sales services }\end{array}$ \\
\hline
\end{tabular}

Source: Author's own study.

As is shown in Table 3, there are many risk factors that have been recognized in UniGlass Polska Sp. z o.o. Therefore, it is worth mentioning here that the basic areas of analysis of risk factors are: human resources (human resources processes management), technical infrastructure (including ICT), innovation processes, knowhow, financial management, marketing and market environment.

Table 3. Basic groups of risk factors in a company UniGlass Polska Sp. z o.o.

\begin{tabular}{|c|c|c|c|c|c|c|}
\hline 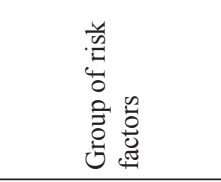 & 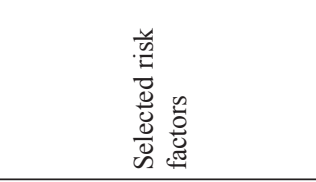 & 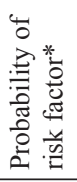 & 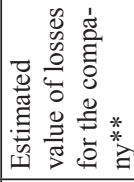 & 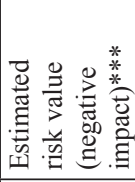 & 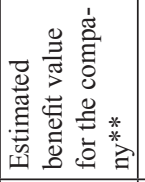 & 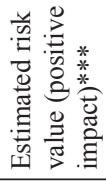 \\
\hline 1 & 2 & 3 & 4 & $5=3 \times 4$ & 6 & $7=3 \times 6$ \\
\hline \multirow{3}{*}{ Risk in IT area } & $\begin{array}{l}\text { Outsiders breaking into the } \\
\text { company's IT system }\end{array}$ & 3 & 5 & 15 & 0 & 0 \\
\hline & $\begin{array}{l}\text { Development and commer- } \\
\text { cialization of own IT sys- } \\
\text { tems (sales to competitors) }\end{array}$ & 3 & 1 & 3 & 4 & 12 \\
\hline & $\begin{array}{l}\text { Implementation and devel- } \\
\text { opment of decision process } \\
\text { automation }\end{array}$ & 3 & 2 & 6 & 4 & 12 \\
\hline \multirow{5}{*}{$\begin{array}{l}\text { Risk in the area of } \\
\text { human resources }\end{array}$} & $\begin{array}{l}\text { Rotation of specialized } \\
\text { managerial staff }\end{array}$ & 2 & 5 & 10 & 1 & 2 \\
\hline & $\begin{array}{l}\text { Rotation of administrative } \\
\text { staff }\end{array}$ & 2 & 3 & 6 & 1 & 2 \\
\hline & $\begin{array}{l}\text { Rotation of production } \\
\text { workers }\end{array}$ & 3 & 1 & 3 & 1 & 3 \\
\hline & $\begin{array}{l}\text { Successful implementa- } \\
\text { tion of mechanisms for } \\
\text { triggering trust between } \\
\text { employees at managerial } \\
\text { level }\end{array}$ & 3 & 3 & 9 & 4 & 12 \\
\hline & Improving production staff & 3 & 1 & 3 & 2 & 6 \\
\hline
\end{tabular}




\begin{tabular}{|c|c|c|c|c|c|c|}
\hline 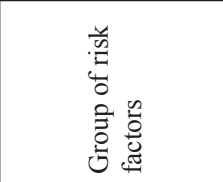 & 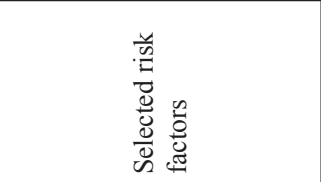 & 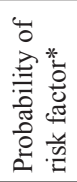 & 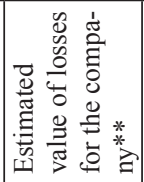 & 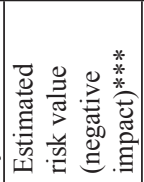 & 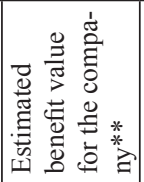 & 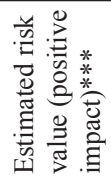 \\
\hline 1 & 2 & 3 & 4 & $5=3 \times 4$ & 6 & $7=3 \times 6$ \\
\hline \multirow{3}{*}{$\begin{array}{l}\text { Risks in the area } \\
\text { of technical infra- } \\
\text { structure }\end{array}$} & Line failure & 4 & 5 & 20 & 0 & 0 \\
\hline & $\begin{array}{l}\text { Keeping up with techno- } \\
\text { logical developments in the } \\
\text { industry }\end{array}$ & 4 & 4 & 16 & 4 & 16 \\
\hline & $\begin{array}{l}\text { Maintaining continuity of } \\
\text { production processes (good } \\
\text { state of machine stock) }\end{array}$ & 3 & 5 & 15 & 4 & 12 \\
\hline \multirow{7}{*}{ Market risk } & $\begin{array}{l}\text { Establishing lasting } \\
\text { relationships with new } \\
\text { customers }\end{array}$ & 5 & 4 & 20 & 3 & 15 \\
\hline & $\begin{array}{l}\text { Maintaining lasting } \\
\text { business relationships with } \\
\text { regular customers }\end{array}$ & 4 & 3 & 12 & 5 & 20 \\
\hline & $\begin{array}{l}\text { Maintaining lasting } \\
\text { relationships with new } \\
\text { suppliers }\end{array}$ & 3 & 5 & 15 & 4 & 12 \\
\hline & $\begin{array}{l}\text { Maintaining lasting } \\
\text { relationships with regular } \\
\text { suppliers }\end{array}$ & 4 & 2 & 8 & 3 & 12 \\
\hline & $\begin{array}{l}\text { Active business of com- } \\
\text { petitors }\end{array}$ & 4 & 3 & 12 & 4 & 16 \\
\hline & Training subcontractors & 4 & 3 & 12 & 5 & 20 \\
\hline & $\begin{array}{l}\text { The effectiveness of the } \\
\text { company's targeted policy }\end{array}$ & 3 & 3 & 9 & 4 & 12 \\
\hline \multirow{4}{*}{ Financial risk } & $\begin{array}{l}\text { Maintaining financial } \\
\text { liquidity }\end{array}$ & 4 & 1 & 4 & 5 & 20 \\
\hline & $\begin{array}{l}\text { Timely settlement of tax } \\
\text { and social security obli- } \\
\text { gations }\end{array}$ & 4 & 1 & 4 & 4 & 16 \\
\hline & $\begin{array}{l}\text { Timely receipt of receiva- } \\
\text { bles from new customers }\end{array}$ & 3 & 3 & 9 & 4 & 12 \\
\hline & $\begin{array}{l}\text { Timely receipt of receiva- } \\
\text { bles from fixed customers }\end{array}$ & 5 & 1 & 5 & 4 & 20 \\
\hline Risk in know-how & $\begin{array}{l}\text { Providing information to } \\
\text { competitors by employees }\end{array}$ & 2 & 5 & 10 & 0 & 0 \\
\hline $\begin{array}{l}\text { Risk in the area of } \\
\text { innovation }\end{array}$ & $\begin{array}{l}\text { Launching innovative } \\
\text { products }\end{array}$ & 5 & 2 & 10 & 5 & 25 \\
\hline Risk in marketing & $\begin{array}{l}\text { Ensuring product visibility } \\
\text { in the market }\end{array}$ & 4 & 3 & 12 & 5 & 20 \\
\hline
\end{tabular}

* The following qualitative scale is accepted for probability: very low (estimate 1), low (estimate 2), average (estimate 3), high (estimate 4$)$ and very high (estimate 5).

** The following qualitative scale is used for the effects (losses/benefits): very low (estimate 1), low (estimate 2), average (estimate 3), high (estimate 4 ) and very high (estimate 5).

*** The risk estimate is the product of the estimated probability and level of effects.

Source: Wereda, Woźniak [2017, p. 486-487]. 
Due to the information listed in Table 3, one of the basic areas of risk is the information system, a product developed by UniGlass Polska Sp. z o.o. This system, despite being successfully implemented in this company, is additionally available to competitors. Seemingly, such an operation can only be a source of danger for the company, but in fact it provides additional benefits - including the fact that it is a source of income, strengthens the position of the company as a leader and innovator in the market, and indirectly stimulates market development through the development of competitors. Furthermore, in the area of human resources management, the level of risk is different for jobs (decision levels). The highest level of risk occurs at the highest levels, which is the result of problems in acquiring new, highly qualified specialists/managers. In addition, large rotation in management positions is related to the need for training, prolonging innovation processes, etc. On the other hand, it can be an additional source of knowledge in the organization (from external specialists) and a factor stimulating the so-called intra-production. The third aspect is the area of technical infrastructure; the main risk factor is the failure of the production line. Such an event can cause high strikes. The probability of its occurrence is also high. Therefore, the state of the infrastructure is monitored and controlled systematically. In addition, the company must keep up with technological innovations so as not to lose pace with the competition. It also requires substantial investment. Basic market activities of UniGlass Polska Sp. z o.o. relate to contacts with key stakeholders, i.e. customers, suppliers, competitors and subcontractors. The risk in the area of market activities is diversified, mainly due to supply-demand factors. For customers, one will notice the impact of factors such as lack of commercial contracts, retention of customers, search for novelties and cheaper products in most cases. On the other hand, the role of suppliers is affected by factors such as: reduction of glass supply in the market, long-term cooperation on the basis of trust and solid trade settlements, and lack of raw materials in the market. It is also worth noting that the price of the company's products includes added value, which includes such items as logistic services, delivery deadlines, high quality, poor product defects, assembly training and so on. In terms of innovative activities and the creation of know-how, it is worth mentioning that the company is safeguarded by law clauses before making information available to the competition by employees. In addition, all know-how of the company is in the "hands" of the President and Commercial Director. The "leak" of sensitive information is therefore limited by the use of information asymmetry. This also has an impact on the processes of creating and implementing innovation. The company is constantly introducing innovative products that are not available in the sector. Production lines are ordered from suppliers, however, when co-creating and guiding the CEO is the "leader" and principal innovator in the innovation process. It is also important that the company's products are recognized on the market, and the company operates mainly on the basis of catalogues and industry materials, as well as whisper marketing - it does not use marketing campaigns. Much attention is also paid to product quality and customer service. At this point, it should also be noted that different risk factors are reported in different risk groups (Table 3). 
As an example, it may be used to estimate the risk in the human resources area, where the rotation of employment in various groups of employees has different levels of risk and the same refers to other persons in the business. It is also interesting to estimate the different levels of risk for permanent and new customers and suppliers.

Table 4. Stakeholders of UniGlass Polska Sp. z o.o. and their impact on the level of trust and the type of risk occurring in the relations: company-environment

\begin{tabular}{|c|c|c|c|c|}
\hline No. & Specification of the organization's stakeholders & $\begin{array}{c}\text { Impact on the } \\
\text { functioning of the } \\
\text { enterprise }\end{array}$ & $\begin{array}{l}\text { The level of trust } \\
\text { on the part of the } \\
\text { company }\end{array}$ & $\begin{array}{l}\text { Level of risk in } \\
\text { relationships }\end{array}$ \\
\hline 1. & Individual clients & BW & ZT & WR \\
\hline 2. & Institutional clients & BW & ZT/ZW & WR \\
\hline 3. & Founding body & BW & ZR/ZW & WR \\
\hline 4. & Managers & $\mathrm{BW}$ & ZR/ZW & WR \\
\hline 5. & Shareholders & $\mathrm{BW}$ & ZR/ZW & WR \\
\hline 6. & $\begin{array}{l}\text { Regulating bodies (National Labour Inspector- } \\
\text { ate, Sanitary-epidemiological service and so on) }\end{array}$ & PW & ZW & SR \\
\hline 7. & Administrative staff & $\mathrm{BW}$ & $\mathrm{OZ} / \mathrm{ZR} / \mathrm{ZW}$ & WR \\
\hline 8. & Production staff & BW & $\mathrm{OZ}$ & SR \\
\hline 9. & Competition & $\mathrm{BW} / \mathrm{PW}$ & $\mathrm{OZ}$ & WR \\
\hline 10. & Providers & $\mathrm{BW}$ & $\mathrm{ZT}$ & WR \\
\hline 11. & Banks and financial institutions & $\mathrm{PW}$ & ZT & WR \\
\hline 12. & Cooperators (subcontractors) & $\mathrm{BW}$ & ZT/ZR & SR \\
\hline 13. & Accreditation and certification institutions & $\mathrm{PW} / \mathrm{BW}$ & ZW & WR \\
\hline 14. & Advisory (consulting) institutions & PW & ZW & WR \\
\hline 15. & Renovation and construction companies & PW & $\mathrm{OZ}$ & SR \\
\hline 16. & Local society & PW & ZR & SR \\
\hline 17. & Local government authorities & PW & ZR & SR \\
\hline 18. & Local industry associations & PW & ZR & NR \\
\hline 19. & Local politicians & PW & $\mathrm{OZ} / \mathrm{ZR}$ & SR \\
\hline 20. & Church & $\mathrm{PW}$ & ZR & NR \\
\hline 21. & Local media (press, radio and television) & $\mathrm{PW}$ & $\mathrm{ZT}$ & SR \\
\hline 22. & Social media (blogs, websites, etc.) & $\mathrm{PW}$ & ZT & SR \\
\hline 23. & Shop owners & PW & ZT & NR \\
\hline 24. & Wholesalers & PW & ZT & NR \\
\hline 25. & Logistics companies & PW & ZT & NR \\
\hline 26. & Companies offering insurance services & PW & ZR/ZW & SR \\
\hline 27. & $\begin{array}{l}\text { Outsourcing companies (e.g. property } \\
\text { protection, accounting, etc.) }\end{array}$ & PW & ZT & WR \\
\hline 28. & $\begin{array}{l}\text { Intermediary institutions in obtaining funds } \\
\text { from the EU }\end{array}$ & PW & $\mathrm{OZ} / \mathrm{ZT}$ & WR \\
\hline 29. & Training companies & $\mathrm{PW}$ & $\mathrm{OZ} / \mathrm{ZT}$ & SR \\
\hline 30 . & $\begin{array}{l}\text { Companies helping to obtain subsidies from } \\
\text { various funds }\end{array}$ & PW & $\mathrm{OZ} / \mathrm{ZT}$ & WR \\
\hline 31. & $\begin{array}{l}\text { Rating companies (companies that create } \\
\text { ratings for industries and sectors) }\end{array}$ & PW & $\mathrm{OZ}$ & NR \\
\hline 32. & Universities & $\mathrm{PW}$ & ZR & NR \\
\hline
\end{tabular}

$\mathrm{BW}$ - direct impact, $\mathrm{PW}$ - indirect impact, $\mathrm{OZ}$ - limited trust, ZT - transaction trust, ZR - trust based on relationships, $\mathrm{ZW}$ - trust based on cooperation, NR - low risk, SR - medium risk, WR- high risk 
With reference to Table 4, it can be noted that the UniGlass company defines quite a large group of stakeholders who, according to the experts surveyed (employees of the company in high managerial positions), have direct influence, that is, all groups of employees, clients or cooperators, as well as those who have indirect effective functioning in business, for example, all companies cooperating in offering services and products, and all other controlling, regulating or advising institutions. Most of the company's stakeholders, according to experts from the company, create a high or medium level of risk in business relations. The high-risk group includes, among others, employees, customers, competitors, suppliers, and cooperating and controlling companies, while the medium-risk group consists of the cooperators, local media, local community, local government or local politicians and other industry institutions. If the trust was determined, the company's representatives agreed that trust based on relations and cooperation is mainly visible in the enterprise itself, i.e. between the management staff, shareholders and selected employees. In the case of external stakeholders, experts have emphasized the importance of local authorities, communities, regional institutions and associations in building trust based on relationships, often both business and personal. Unfortunately, traditional and modern media, owners of local wholesalers or stores, suppliers and individual clients are provided with transactional trust. Confined trust of the managerial staff has been mainly to production workers and some administrative employees, competitors, rating and training companies, intermediary companies in obtaining EU funds as well as service companies.

\section{Conclusions}

Numerous scholars have concluded that trust is important in an organization. However, this is difficult to build and maintain over a long period. Characteristics of trust that can be considered as obstacles to its building and maintenance have been identified. First, there are misunderstandings and confusion about what trust is. Economists view trust as more rational and calculative; sociologists underline the reliability of the word or promise and psychologists see trust as a personality trait. The second characteristic is that building trust is an interactive process involving at least two individuals learning about each other's trustworthiness. The process is dynamic; trust is difficult to build and very easy to destroy. The third characteristic is that there is no absolute certainty that the trust will be honoured in the future [Wereda et al., 2016, p. 55]. Based on the literature, as well as the case analysed - UniGlass Polska Sp. z o.o. - a model of building stakeholder engagement in the functioning of the organization has been presented, which shows the connection of trust, risk, commitment and communication in building relationships with all interest groups (Figure 3). 


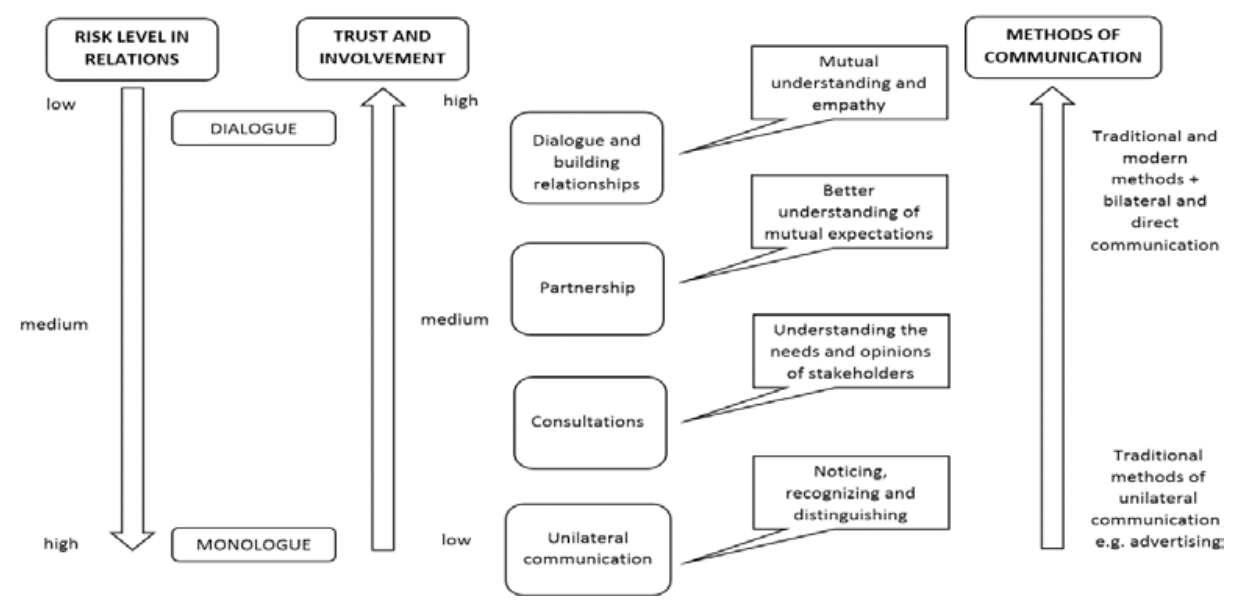

Figure 3. The model of building stakeholder engagement in the functioning of the organization - in terms of trust, communication and risk

Source: Author's own elaboration based on Dąbrowski [2010, p. 187].

\section{References}

Benson-Armer, R., Stickel, D., Successful team leadership is built on trust, "Ivey Business Journal” 2000, Vol. 65(5).

Bourne, L., Stakeholder relationship management. A maturity model for organisational implementation, Gower, Farnham 2009. DOI: 10.4324/9781315610573.

Ciancutti, A., Steding, T.L., Built on Trust. Gaining Competitive Advantage in Any Organization, Contemporary Books, Chicago 2001.

Covey, St. M. R., Building trust. How the best leaders do it, "Leadership Excellence" 2009.

Dąbrowski, T.J., Reputacja przedsiębiorstwa. Budowanie kapitalu zaufania, Wolters Kluwer, Kraków 2010. Domańska-Szaruga, B., Simiński, P., Trust and business risk in a research institute's operations, „Zeszyty Naukowe Uniwersytetu Przyrodniczo-Humanistycznego w Siedlcach. Administracja i Zarządzanie" 2017, nr 115 .

Fawcett, S.E, Jones, S.L., Fawcett, A.M., Supply chain trust: The catalyst for collaborative innovation, "Business Horizons" 2012, Vol. 55(2). DOI: 10.1016/j.bushor.2011.11.004.

Freeman, R.E., A stakeholder theory of the modern corporation, [in:] T.L. Beaucham, N.E. Bowie (eds.), Ethical Theory and Business, Pearson/Prentice Hall, New Jersey 2004.

DOI: 10.3138/9781442673496-009.

Freeman, R.E., Strategic Management: A Stakeholder Approach, Pitman, Boston 1984.

DOI: 10.1017/cbo9781139192675.003.

Fukuyama, F., Zaufanie. Kapitat społeczny a droga do dobrobytu, PWN, Warszawa-Wrocław 1997.

Galford, R., Drapeau, A.S., The Trusted Leader. Bringing Out the Best in Your People and Your Company, Free Press, New York 2002.

Grudzewski, W.M., Hejduk, I.K., Sankowska, A., Wańtuchowicz, M., Zarządzanie zaufaniem w przedsiębiorstwie: koncepcja, narzędzia, zastosowanie, Wolters Kluwer, Kraków 2009.

Hopkin, P., Fundamentals of Risk Management: Understanding, Evaluating and Implementing Effective Risk Management, Kogan Page Limited, London-Philadelphia-New Delhi 2010. 
Jończyk, J., Zaufanie jako fundamentalny czynnik proefektywnościowych relacji w organizacji, [in:] A. Wasiluk (red.), Nowoczesne podejścia do zarządzania organizacjami, Difin, Warszawa 2009.

Jończyk, J., Relacje oparte na zaufaniu a doskonalenie jakości ustug publicznych, „Współczesne Zarządzanie" 2010, $\mathrm{nr} 4$.

Lane, C., Introduction: Theories and issues in the study of trust, [in:] C. Lane, R. Bachman (eds.), Trust Within and Between Organizations, Conceptual Issues and Empirical Applications, Oxford University Press, Oxford 1998.

Lewicki, R.J., Bunker, B.B., Developing and maintaining trust in work relationships, [in:] R.M. Kramer, T.R. Tyler (eds.), Trust in Organizations, Frontiers of Theory and Research, Sage Publications, Thousand Oaks 1996. DOI: 10.4135/9781452243610.n7.

Lewicki, R.J., McAllister, D.J., Bies, R.J., Trust and Distrust: New Relationships and Realities, “Academy of Management Review" 1998, Vol. 23/3. DOI: 10.2307/259288.

McAllister, D.J., Affect- and cognition-based trust as foundations for interpersonal cooperation in organizations, "Academy of Management Journal" 1995, Vol. 38. DOI: 10.2307/256727.

Murphy, D., Understanding Risk: The Theory and Practice of Financial Risk Management, Taylor \& Francis Group, LLC, Boca Raton 2008. DOI: 10.1201/9781584888949.

Paliszkiewicz, J., Zaufanie w zarzadzaniu, Wydawnictwo Naukowe PWN, Warszawa 2013.

Porras, S.T., Clegg, S., Crawford, J., Trust as networking knowledge: Precedents from Australia, "Asia Pacific Journal of Management” 2004, Vol. 21. DOI: 10.1023/b:apjm.0000036467.45516.97.

Quality Book of UniGlass Polska Sp. z o.o., 2011.

Sztompka, P., Kulturowe imponderabilia szybkich zmian społecznych: zaufanie, lojalność, solidarność, [in:] idem, Imponderabilia wielkiej zmiany. Mentalność, wartości i więzi społeczne czasów transformacji, PWN, Warszawa-Kraków 1999.

Sztompka, P., Zaufanie fundament spoleczeństwa, Wydawnictwo Znak, Kraków 2007.

Szwajca, D., Zarzadzanie reputacja przedsiębiorstwa. Budowa i odbudowa zaufania interesariuszy, CeDeWu, Warszawa 2016.

Wereda, W., Orientacja na zaufanie a budowa relacji z interesariuszami w organizacji, „Prace Naukowe Uniwersytetu Ekonomicznego we Wrocławiu" 2015, nr 376. DOI: 10.15611/pn.2015.376.15.

Wereda, W., Paliszkiewicz, J., Lopes, I.T., Woźniak, J., Szwarc, K., Intelligent Organization (IO) towards contemporary trends in the process of management - selected aspects, Military University of Technology, Warsaw 2016.

Wereda, W., Woźniak, J., Risk in building the intelligent organization model, [in:] F. Pînzaru, A. Zbuchea, C. Brătianu, E.M. Vătămănescu, A. Mitan (eds.), Shift! Major Challenges of Today's Economy, Tritonic, Bucharest 2017.

Woźniak, J, Wereda, W. (red.), Mapa ryzyka w zarządzaniu organizacją. W kierunku organizacji opartej na innowacjach i kulturze ryzyka. Studia przypadków oraz dobre praktyki, CeDeWu, Warszawa 2018.

Wójcik, J., Idee Web 2.0 i prosumenta jako przejawy mitologizacji wspótczesnego świata, [in:] A. Zaorska (red.), Chaos czy twórcza destrukcja? Ku nowym modelom w gospodarce i polityce, Oficyna Wydawnicza SGW, Warszawa 2011.

Zand, D.E., Trust and managerial problem solving, “Administrative Science Quarterly" 1972, Vol. 17. DOI: $10.2307 / 2393957$.

Zucker, L.G., Darby, M.R., Brewer, M.B., Peng, Y., Collaboration structure and information dilemmas in biotechnology: Organizational boundaries as trust production, [in:] R.M. Kramer, T.R. Tyler (eds.), Trust in Organizations, Frontiers of Theory and Research, Sage Publications, Thousand Oaks 1996. DOI: 10.4135/9781452243610.n6. 


\section{Model budowania zaangażowania interesariuszy w funkcjonowanie organizacji - zaufanie a ryzyko}

Celem opracowania było przedstawienie określonych elementów modelu budowania zaangażowania interesariuszy $\mathrm{w}$ działanie przedsiębiorstwa oraz zidentyfikowanie określonych grup ryzyka i propozycji działań ograniczających negatywne skutki ryzyka biznesowego poprzez oparcie relacji z interesariuszami nie tylko na sformalizowanych zasadach określających zasady współpracy, ale przede wszystkim na budowaniu zaufania w tych relacjach na określonym przykładzie. Badanie poprzedzono syntetycznym ujęciem problematyki i zaufania w relacjach $\mathrm{z}$ interesariuszami oraz przedstawiono proces identyfikacji i analizy ryzyka w działalności biznesowej firmy UniGlass Sp. z o.o. Rozważania stanowią element szerszych badań nad implementacją modelu budowania zaangażowania zdywersyfikowanych interesariuszy w działalności biznesowej opatrzonej ponoszeniem ryzyka na wielu poziomach. W ramach różnorodnych form współpracy wymaga się od przedsiębiorstw wyszukiwania czynników ryzyka, które są szansą bądź zagrożeniem w budowaniu relacji lub we współpracy opartej na zaufaniu z innymi podmiotami.

\section{Model of Building Stakeholder Engagement in the Functioning of the Organization - Trust and Risk}

The aim of this study was to present the specific elements of the model of building stakeholder engagement in the operation of a company and identify specific risk groups and proposals that mitigate the negative effects of business risk by building relations with stakeholders, not only on formalized principles defining the principles of cooperation, but above all on building trust in these relationships. The study adopts a synthetic approach to issues and trust in relations with stakeholders, as well as a process of identification and analysis of risk in the business operations of UniGlass Sp. z o.o., is presented. The study considers the implementation of the model of building the involvement of diversified stakeholders in business activities who bear the risk at many levels. As part of various forms of cooperation, enterprises are required to search for risk factors that constitute an opportunity or a threat to building relationships or cooperation based on trust with other entities. 